\title{
Correction to: Renal complications in coronavirus disease 2019: a systematic review
}

Taichiro Minami ${ }^{1,2^{*}}$, Yasunori Iwata ${ }^{2}$ and Takashi Wada ${ }^{2}$

Correction to: Inflamm Regener 40, 31 (2020)

https://doi.org/10.1186/s41232-020-00140-9

Following publication of the original article [1], the authors reported an update in reference number 40 .

The original reference number 40 is:

40. Kashi AH, Fallah-Karkan M, Amini E, Vaezjalali M. The presence of COVID-19 in urine: a systematic review and meta-analysis of the literature. medRxiv. 2020. https://doi.org/10.1101/2020.05.15.20094920.

The updated reference number 40 is:

40. Kashi AH, De la Rosette J, Amini E, Abdi H, FallahKarkan M, Vaezjalali M. Urinary Viral Shedding of COVID-19 and its Clinical Associations: A Systematic Review and Meta-analysis of Observational Studies. Urol J. 2020 Sep 5;17(5):433-441. doi: https://doi.org/ 10.22037/uj.v16i7.6248. PMID: 32888186.

The original article [1] has been updated.

Published online: 23 July 2021

\section{Reference}

1. Minami T, Iwata Y, Wada T. Renal complications in coronavirus disease 2019: a systematic review. Inflamm Regener. 2020;40:31 https://doi.org/10.1186/ s41232-020-00140-9.

* Correspondence: tminami1@bwh.harvard.edu

'Renal Division, Department of Medicine, Brigham and Women's Hospital, 4 Blackfan Street, Boston, MA, USA

${ }^{2}$ Department of Nephrology and Laboratory Medicine, Kanazawa University, Kanazawa, Ishikawa, Japan

(c) The Author(s). 2021 Open Access This article is licensed under a Creative Commons Attribution 4.0 International License, which permits use, sharing, adaptation, distribution and reproduction in any medium or format, as long as you give appropriate credit to the original author(s) and the source, provide a link to the Creative Commons licence, and indicate if changes were made. The images or other third party material in this article are included in the article's Creative Commons licence, unless indicated otherwise in a credit line to the material. If material is not included in the article's Creative Commons licence and your intended use is not permitted by statutory regulation or exceeds the permitted use, you will need to obtain permission directly from the copyright holder. To view a copy of this licence, visit http://creativecommons.org/licenses/by/4.0/. 